\title{
ENGLISH FOR SPECIFIC PURPOSES - CHALLENGES FOR POST-GRADUATION OUTCOMES
}

\author{
Rodica Silvia Stan \\ University of Agricultural Sciences and Veterinary Medicine, Cluj Napoca (Romania)
}

\begin{abstract}
The current level of global economy and the continuous increase of international communication in various fields involve a wide landscape of career opportunities and imply well-prepared professionals. Most students, future specialists, need to become proficient in a foreign language, usually English, in order to meet a predictable range of communicative needs. Thus, the demand for English for Specific Purposes (ESP) is expanding in technical universities. This requires a special language teaching approach, that combines English language teaching and the students' professional concerns. The present paper explains an experiment that consists of teaching ESP in an academic context, but under unusual circumstances. The professional purpose is not only the shaping of future engineers or economists, but also the desire to make language learning interesting, attractive and useful. The novelty of the experiment consists of moving the language classes from the usual classroom into the place where the students perform their practical activities. The new professional environment, which increasingly involves certain accomplishments, is a real provocation for students, more and more interested in terminology acquisition. The students' universe has no limits regarding the power of information conveyed in the foreign language. The lexical material supposed to be acquired is easily kept in mind because the new linguistic material is linked to actual facts and situations from the surrounding environment. Students become more creative and more confident in their professional capacity. Moreover, the course, taught under such circumstances, requires flexibility from the teacher in his choice of methods and techniques, but also the obligation to stick to the requirements of the curriculum.
\end{abstract}

Keywords: Communication, terminology, practice, language proficiency, professional environment.

\section{Introduction}

The current level of global economy involves a wide landscape of career opportunities and implies well-prepared professionals. This is why graduate students of technical universities should become successful members of the global workforce. Most students, future specialists, need to become proficient in a foreign language, usually English, in order to meet a predictable range of communicative needs. In a global economy, English is, obviously the queen, and knowledge of English is increasingly a prerequisite for a high-paying job and a career in a growing variety of fields. The best environment to achieve this purpose is the language course offered by the universities the students belong to.

\section{Design}

A rising number of scientific university programmes in Europe include workplace experiences as elements of educational provisions. Students realize more and more that the opportunity to engage in such activities promote their learning and prospect their post-graduation outcomes. Educators, on the other hand, are engaged in challenges to provide useful and productive experiences for their students. This tendency is even more obvious in agricultural universities, where, however theoretically the teaching process is conceived, "learning by doing" is the best method that the university programme can offer. Students always keep in touch with the most provoking challenges of society and, when it comes to global ambitions, most of them wish to be prepared to get a place in a global environment. According to the British linguist David Graddol, there will be two billion people speaking or learning English within a decade. Everywhere, today and obviously tomorrow, English will be present in the lives of all people around the world. It is the most frequent tool for operating in most fields: banking, politics, diplomacy, science, travelling, internet. The display of computer technologies - especially the Internet - have expanded the use of English to the 
remotest corners of the globe, and the new generations from Seoul to Athens to Santiago de Chile are all growing up with a knowledge of English. Moreover, as corporations become truly multinational, English tends to become their official corporate language, regardless of the company's location. As the European Union expands and becomes more multi-lingual, it too has shifted more and more to English. The ultimate insult to continental powers is that, even though the UK stay out of the EU, its language is and will be English.

\section{Objectives}

According to Tuula Lehtonen, "...the ability to communicate is paramount." "Languages play a role both in recruitment and at work and (inter)cultural knowledge and communication skills are important." Undergraduate students who are preparing for careers in the global economy by taking courses in English, are aware of all these facts and they know how useful thorough knowledge of English for Specific Purposes (ESP) is. They are in the process of developing expertise that will enable them to succeed in their future internships and future jobs. They need to master communication skills in English. Young people are aware that English is a world language, the dominant language of science, computing and academia in general. In technical universities ESP is taught in an academic environment where the aim is not only the formation of future specialists in economics, agriculture, or horticulture, but also the desire to make students enjoy English classes for the way teaching takes place, for the manner of delivering information and for the passion for this language transmitted during classes. Moreover, we consider that teaching ESP leaves room for creativity, opens gates towards improving general knowledge, towards a universe where there are no limits regarding the power of information conveyed in English. Because practical work is very important for students of the University of Agricultural Sciences and Veterinary Medicine, we started an experiment which involved moving out of the usual lecture room for English into the students' work placement: green houses for students of Horticulture, banks, tourist information centres and consultancy centres for students of Economics, breweries and milk processing factories for students of Food Processing.

\section{Methods}

The participants in the experiment were students of Biology, Finance, Business and Management. The experiment was very provocative and complex. After sending their Cvs, the students were delighted to be accepted by companies which might represent their future workplaces and were surprised to have the chance to learn English at the same time. Their concern for learning English was different: they became more motivated and learned faster.

\subsection{Students of finance, business and management}

English has long been the language of finance. As financial markets become ever more global and round-the-clock operations, the importance of English keeps increasing. The English classes with students of Business and Management moved out from the usual classroom into a bank during the students' placement. Before their placement, the students had acquired the new terminology and then practiced it in various ways to reinforce the new vocabulary. Here are some of the words that all the students were supposed to know:

Account: There is a checking account and a savings account. The checking account (or current account in British English) allows taking out money anytime. The savings account allows saving money and also earning interest. e.g. They needed to transfer some money from the savings account to the checking account so that they could pay for the new GPS they wanted to buy balance.

Balance is the money someone has in an account. This is the difference between what someone spends (debits) and what someone receives (credits). e.g. He always checks his balance before completing a transaction.

Credit: Credit is the money a bank lends someone. Credit can also refer to the financial reputation someone has when considering borrowing money from a bank. A credit card is a card that allows spending more money than someone has, but then interest must be paid. The word credit can also be used in a general sense: to give someone credit, means to acknowledge his efforts or worth. e.g. The credit of our company was good, so we didn't expect the bank to reject our loan application.

Debit: Debit means money taken out of the bank account or money someone owes. A debit card allows the use of money in someone's account by paying in stores or online. This card can also be used for getting money from a cash machine or ATM. This word can be used as a verb: to debit money means to take out money from an account. e.g. They always use debit a card, so that not to be tempted to spend more money from the account. The bank debited the money from his account. 
Loan: A loan is money borrowed from a bank or another institution or person. The bank lends (gives) the money, and the customer borrows (receive) it. The bank is the lender, and the customer is the borrower. e.g. They needed a loan to buy a building for their company, but they couldn't find a lender.

Debt: A debt is an amount of money that is owed. The word can be used in a general way: A person who is in debt to someone, owes him a favor or is grateful for something. e.g. They could not pay their debt, so they had to sell part of their land.

While in the usual lecture room, the students wrote sentences with the new words in order to use them in new contexts and carried out role-play activities in order to reinforce the new vocabulary, but this time it is a real life situation. Things really happen. A group of eight students, accompanied by their teacher of English, do their placement in a bank. The professional target is twofold: learning about banking and improving the English terminology necessary for working in a bank. The student is sitting at his desk, a real desk, in a bank, a real bank, and there is a customer, a real customer, in flesh and blood, in front of him. It is an information desk for foreign customers and the student in question has to speak English. An employee of the bank is sitting by his side, prepared to help or step in. The teacher of English is also there, close to the desk, watching carefully, taking notes and preparing the next terminology session, according to the gaps and requirements that he notices. Every 20 minutes the student is replaced by a colleague of his, so that during three hours all the eight students in the group perform this activity. The bank offers a room, which becomes the actual classroom, where students gather after performing the "bank clerk" role. From this point on the teacher can discuss all the words, expressions, idioms, that he noticed his students need discussing. He adds a whole list to what has been previously taught. An employee of the bank attends this meeting as well in order to give extra information and to answer the students' questions. Thus, the actual work performed by the student during his placement goes hand in hand with learning English. During this activity other words and expressions needed to be discussed. The students understood the actual meaning of a lot of terms, which they had previously just heard or learned by heart. Here are some of the new terms that needed to be discussed:

Interest Rate: If you borrow money from a bank, you'll need to pay it back. In addition to this, you'll need to pay interest. The amount of interest is decided by an interest rate, which is calculated for a given period of time. If you have a savings account, the bank will pay you interest for being able to use your money over a certain period of time.

To overdraw: To overdraw is to try to withdraw more money than you have in your account. In this case, you generally have to pay some extra fees. It's advisable (a good idea) to pay attention to your balance so you don't overdraw money. e.g. They were careful not to overdraw money from their account, because the penalties are quite high with his bank.

Direct Debit: This is an arrangement to make regular payments of different amounts, usually for utilities (services like electricity and water) or credit card bills. By using direct debit, you avoid having to make monthly transactions. e.g. The company uses a direct debit for its mobile phones bill.

Safety Deposit Box: A safety deposit box is a safe that the bank rents for people to store their valuable items. e.g. After he came back from the US, he decided to keep his important documents in a safety deposit box.

Mortgage: A mortgage is an agreement by which someone can borrow money from a bank to buy a house. The bank becomes the owner of the house until the debt is paid up. e.g. Many people need to take out a mortgage to buy a house.

Collateral: This is something, like a house, that's used as a guarantee (assurance or backup) when taking out a loan. If the borrower cannot pay the debt, the bank becomes the owner of the collateral. e.g.: They did not have any collaterals, so they decided to take out a mortgage.

Appraisal: Appraisal is the evaluation of the value of a property, usually done by a bank representative. An appraisal is usually carried out before taking out a mortgage. e.g. He wanted to use his land as collateral for the loan, but first the bank needed to appraise its value.

Payoff: This is the complete payment of a loan. e.g. He was feeling relieved that he had completed the payoff of the debt.

Learning banking vocabulary will not only help students when working in or doing business with a bank. They will also feel more confident when doing any kind of business in English, which means that they will be successful business people.

\subsection{Students of biology}

The ESP experiment with students of Biology started in the classroom, with a discussion on environment and pollution. The checking of the vocabulary acquired in high school was important because some of the students may not have learned the simple science words in high school and they could have difficulty understanding more advanced vocabulary connections. Only after this stage more complicated 
science materials can be presented. Usually students get involved easily because talking about environment is a topic they enjoy. This subject of science involves the usage of many biology terms, which essentially need to be comprehended correctly. People involved in the science field encounter innumerable jargons during their study, research, or work. Moreover, since science is a part of everyone's life, it is something that is important to all individuals. Here are some words the meaning of which the students proved to know:

Bacterium: a single celled, omnipresent organisms appearing in spiral, spherical or rod shape.

Biomass: Total mass of living matter present in a given habitat, expressed as volume of organisms per unit of habitat's volume or weight per unit area.

Biotechnology: Use of living organisms, tissue or cells for the manufacture of drugs or products intended for human benefit.

Blade: The broad, flattened, conspicuous part of the lead called lamina that is distinguished from the petiole or stalk.

Bark: Tissues of the vascular cambium forming tough layer on the outer region of the woody stems and roots.

Budding: Type of asexual reproduction involving formation of new cells from protrusions arising from mature cells. Yeast reproduces via budding.

Development: Changes pertaining to the growth and differentiation of plant cells into various tissues and organs.

Embryo: The immature sporophyte formed after fertilization from the zygote in the archegonium or ovule.

Family: Category of classification above the genus category and below the order category.

Fruit: In angiosperms, the ripened ovary wall produced from the flower, usually containing seeds.

Ecology: Branch of biology involving study of interactions of organism with the environment and with each other.

Petals: The colored segments of the corolla of the flower, which most often are involved in drawing in pollinating agents.

Photosynthesis: Photosynthesis is a plant activity which includes the synthesis of complex organic substances, peculiarly saccharides, from carbon dioxide, water, and inorganic salts, utilizing sunlight as a source of energy and with the help of chlorophyll and associated pigments. Plant Anatomy: Study of the internal structure of the plant.

Plant Physiology: The study of plants, which involves processes such as nutrition, reproduction, and other functions.

Plant Taxonomy: The science that refers to the identifications, description, naming, and classification of plants according to their unique characteristics.

Root: Organ of the plant situated below the ground and absorbs water and mineral salts. Buds, leaves or nodes are absent in root.

Transpiration: In botanical studies, the process of emission of water vapor from the plant leaves is known as transpiration.

After the classical lecture hall the students were moved to laboratory, where they performed their practical work. Laboratory environments are excellent settings for ESP Biology students. They are less intimidating places to communicate with other students versus large group discussions with the entire class, they provide an excellent way to use the vocabulary in a more casual setting and a way to work with peers in a less pressure-filled environment. The laboratories we used were the Microbiology Laboratory, the Floristry Laboratory, the Tree Growing Laboratory and the Viticulture Laboratory. All the groups of students were international because they included Erasmus students from many European countries, thus the language used was exclusively English. Alongside with the Biology trainer the ESP teacher was present and offered the necessary explanations. Here are some of the words the students learned, or words the meaning of which was cleared out in this relaxed environment:

Achene: A simple, single-seeded, dry, indehiscent fruit comprising one seed attached to only the base of the pericarp.

Aerobic Cellular Respiration: Part of cellular respiration, and plays a significant role in producing energy required to carry out different functions of the plant. It requires oxygen for the process.

Biennial: Plants requiring two seasons to complete their life cycle. The first season growth is purely vegetative and the second one bears fruit.

Biomass: Total mass of living matter present in a given habitat, expressed as volume of organisms per unit of habitat's volume or weight per unit area.

Food Chain: Natural chain of organisms, in which each organism of the chain feeds on members below it in the chain, and is consumed by organisms above it in the chain.

Gene: Basic unit of heredity, involving sequence of nucleotide containing necessary information for the structure and metabolism of an organism. 
Gene Bank: It is a way of preserving plants and seeds for their germ plasm.

Genetic Engineering: Introduction of genes from one DNA form into another, by artificial means is called genetic engineering.

Peduncle: It is the stem which holds either a bunch of flowers or a solitary flower.

Pericarp: It relates to the matured and diversely altered walls of a plant ovary.

Plasmodium: Body of slime mold, which is a large mass of living substance with hundreds or thousands of karyons. Plasmodium ingest fungal spores, bacteria and other tiny protozoans.

Recombinant DNA: DNA molecule created either by crossing over in meiosis or under laboratory environment (in vitro). It is formed when DNA from at least two organisms is taken.

Taxis: The movement of a cell that is triggered by external stimulus, towards or away from the stimulus source, is known as taxis.

Transgenic Plant: A plant which contains DNA inserted by some form of genetic engineering is known as transgenic plant.

Zygosporangium: Large multinucleate sporangium produced by the fusion of two compatible hyphae in Zygomycete fungi.

Zygote: Diploid cell conducted by the fusion of two gametes.

Whenever possible the students took field trips to places like the Botanical Garden from Cluj and to various forests in Transylvania.

\section{Conclusions}

The endeavours to conceive this ESP experiment outside the lecture room proved to be successful. Due to the new circumstances of studying the foreign language students became more interested and highly motivated. The lexical material supposed to be acquired was easily kept in mind because the words and phrases were linked to actual facts and situations. Students become more creative and more confident in their professional capacity. The intercourse with their international peers brought them self confidence and opened gates to a desire for an international experience. The students will also feel more confident when doing any kind of business in English. This methodological challenge made the teaching of English not only interesting and attractive, but also very useful. The new methods conceived and applied provide different learning opportunities, which address the needs of learners, who realize that the ability to communicate is paramount.

\section{References}

Bain, J.D., Ballantyne R., Mills, C., \& Lester, N.C., Reflecting on practice: Student teachers' perspectives. Flaxton:Post Pressed, 2002.

Diaz-Rico, L. T. and Weed, K. Z. (2002). The cross-cultural, language, and academic development handbook: A complete K-12 reference guide (2nd edition) Boston: Ally \& Bacon

Hindle, T. (2003). The third age of globalization. The World in 2004.The Economist, pp.109-110.

Hunter, C.A., Pearson, D., Interculturalization and teacher education: Theory to practice. London. Routledge Publishers, 2015.

Kameda, N. (2005). A research paradigm for international business communication. Corporate Communications: An International Journal, 10(2), 168-182

Klein, N. (2002). Fences and Windows.London: Flamingo.

Lehtonen, T., "Practitioner Research as a Way of Understanding My Work: Making Sense of Graduates' Language Use" in Y. Kirkgoz, K. Dikilitas (eds.) Key Issues in English for Specific Purposes in Higher Education. Springer. 2018

Tin, T.B. "Stimulating Student Interest in Language Learning: Theory, Research and Practice". London: Macmillan Publishers, 2016. 